\title{
Sphingoid bases from sea cucumber induce apoptosis in human hepatoma HepG2 cells through p-AKT and DR5
}

\author{
ZAKIR HOSSAIN $^{1,2}$, TATSUYA SUGAWARA ${ }^{1}$ and TAKASHI HIRATA ${ }^{1}$ \\ ${ }^{1}$ Division of Applied Biosciences, Graduate School of Agriculture, Kyoto University, Kyoto 606-8502, Japan; \\ ${ }^{2}$ Department of Human Nutritional Sciences, University of Manitoba, Winnipeg, Manitoba R3T 2N2, Canada
}

Received August 21, 2012; Accepted November 2, 2012

DOI: $10.3892 /$ or.2013.2223

\begin{abstract}
Biofunctional marine compounds have recently received substantial attention for their nutraceutical characteristics. In this study, we investigated the apoptosis-inducing effects of sphingoid bases prepared from sea cucumber using human hepatoma HepG2 cells. Apoptotic effects were determined by cell viability assay, DNA fragmentation assay, caspase- 3 and caspase- 8 activities. The expression levels of apoptosis-inducing death receptor-5 (DR5) and p-AKT were assayed by western blot analysis, and mRNA expression of Bax, GADD45 and PPAR $\gamma$ was assayed by quantitative RT-PCR analysis. Sphingoid bases from sea cucumber markedly reduced the cell viability of HepG 2 cells. DNA fragmentation indicative of apoptosis was observed in a dose-dependent manner. The expression levels of the apoptosis inducer protein Bax were increased by the sphingoid bases from sea cucumber. GADD45, which plays an important role in apoptosis-inducing pathways, was markedly upregulated by sphingoid bases from sea cucumber. Upregulation of PPAR $\gamma$ mRNA was also observed during apoptosis induced by the sphingoid bases. The expression levels of DR5 and p-AKT proteins were increased and decreased, respectively, as a result of the effects of sphingoid bases from sea cucumber. The results indicate that sphingoid bases from sea cucumber induce apoptosis in HepG2 cells through upregulation of DR5, Bax, GADD45 and PPAR $\gamma$ and downregulation of p-AKT. Our results show for the first time the functional properties of marine sphingoid bases as inducers of apoptosis in HepG2 cells.
\end{abstract}

Correspondence to: Dr Zakir Hossain, Department of Human Nutritional Sciences, University of Manitoba, Winnipeg, Manitoba R3T 2N2, Canada

E-mail: hossain5@cc.umanitoba.ca

Abbreviations: DR, death receptor; GADD, growth arrest DNA damage; PPAR, peroxisome proliferator-activated receptor; GlcCer, glycosylceramides

Key words: sea cucumber, sphingoid bases, apoptosis, human hepatoma cells

\section{Introduction}

The highest liver cancer rates are found in East and South East Asia and in Central and Western Africa. Developing countries contribute more than $80 \%$ of the cases. Chronic hepatitis B virus infection accounts for approximately $60 \%$ of the total liver cancer cases in developing countries and for approximately $23 \%$ of the cancer cases in developed countries, while hepatitis $\mathrm{C}$ virus infection accounts for approximately $33 \%$ of the total liver cancer cases in developing countries and for approximately $20 \%$ in developed countries $(1,2)$. Diet is involved in the risk of hepatocellular carcinoma (HCC). It has been shown that red meat and saturated fat are associated with increased chronic liver disease and HCC. A diet that is rich in polyunsaturated fatty acids and, possibly, $\beta$-carotene can reduce the risk of HCC (3). Therefore, an appropriate diet might be a potential tool to prevent HCC.

Sphingolipids and their metabolites, including ceramides, sphingosine, and sphingosine-1-phosphate, play important roles in cellular signaling, such as in proliferation, apoptosis, cellular senescence, growth arrest and differentiation in a variety of cells $(4,5)$. Ceramide is generated from sphingomyelin upon diverse apoptotic stimuli and transfers the death signal, which is the so-called second messenger. Ceramide induces apoptosis by inhibiting a variety of pro-growth signal kinases, including AKT and PKC, with direct activation of protein phosphatases (6). Sphingolipids have a dual role within the cell, acting as key structural components of membranes as well as serving as bioactive second messengers. Central to the chemical backbone of all sphingolipids, sphingosine represents an intermediate linking the metabolism of ceramide to sphingosine-1-phosphate. Cellular levels of sphingosine are controlled by the action of ceramide synthase or sphingosine kinase, which are responsible for the formation of ceramide and sphingosine-1-phosphate, respectively. Conversely, sphingosine may be formed by the action of ceramidase from ceramide or sphingosine-1-phosphatase from sphingosine-1phosphate $(7,8)$.

Physiologically active substances including glycosylceramide (GlcCer) and related compounds have been extracted from a variety of sea cucumber species $(9,10)$. Dry sea cucumber contains $200 \mathrm{mg}$ glycosylceramides per $100 \mathrm{~g}$ (11). GlcCer used as a food ingredient has been isolated from various plant sources, but their content is very low $(1-40 \mathrm{mg} / 100 \mathrm{~g}$ 
dry weight) (12). Thus, sea cucumber may be suitable as a dietary source of sphingolipids. However, the sphingoid base structures in sea cucumber are more complicated than those in mammals and there is little information regarding the nutritional function of these sphingoid bases that are not found in mammals $(13,14)$. Sphingoid bases prepared from wheat flour cerebroside were found to suppress the growth of human colorectal cancer DLD-1 cells through apoptosis (15). Apoptosis was also induced in human colon cancer cells by plant and fungus sphingoid bases (16). In addition, sphingosine induced apoptosis in hippocampal neurons and astrocytes by activating caspase-3/-9 (17).

Peroxisome proliferator-activated receptor $\gamma(\operatorname{PPAR} \gamma)$ has been identified and extensively studied. Several recent studies have shown that most human tumors express PPAR $\gamma$, and there is evidence that PPAR $\gamma$ ligands have antitumor activity (18-25). PPAR $\gamma$ has been the focus of research as a target molecule to prevent cancer (26-28). The upregulation of PPAR $\gamma$ by bitter gourd seed oil containing 9-cis, 11-trans, 13-trans-conjugated linolenic acid was observed (29). In addition, the Bax and the growth arrest and DNA damage inducible gene 45 (GADD45) are known to have important roles in the pathways of growth inhibition and apoptosis induction in many types of cancer cells $(30,31)$. Increased expression of GADD family genes is frequently observed in response to agents that trigger apoptosis $(32,33)$. In this study, the possible pathways of apoptosis induced by sphingoid bases from sea cucumber in human hepatoma HepG2 cells were examined.

\section{Materials and methods}

Preparation of sphingoid bases. Sphingoid bases were prepared from sea cucumber and maize by a silica gel column after lipid extraction and saponification as previously described $(11,34)$. 4,8-Sphingadienine (d18:2) from maize sphingoid bases and 4,8,10-sphingatrienine (d18:3) and 9-methyl-4,8,10-sphingatrienine (d19:3) from sea cucumber sphingoid bases (Fig. 1) were purified by HPLC $(11,34)$.

Cell culture. HepG2 cells were obtained from the Human Science Research Resources Bank, Osaka, Japan. HepG2 cells were grown in 100-mm dishes containing Dulbecco's modified Eagle's medium with $100 \mathrm{IU} / \mathrm{ml}$ penicillin, $100 \mu \mathrm{g} /$ $\mathrm{ml}$ streptomycin, and $10 \%$ heat-incubated fetal bovine serum in a $95 \%$ air-5\% $\mathrm{CO}_{2}$ atmosphere at $37^{\circ} \mathrm{C}$. Subculturing was carried out every 3 days at a concentration of $5 \times 10^{4}$ cells $/ \mathrm{ml}$.

Cell viability assay. Aliquots of $1 \times 10^{5} \mathrm{HepG} 2$ cells were seeded into 96-well microplates containing $100 \mu 1$ of growth medium/well. The plates were preincubated without any treatment for $24 \mathrm{~h}$ at $37^{\circ} \mathrm{C}$. The sphingoid bases were dissolved in ethanol and diluted into the culture medium (the final concentration was $0.1 \%$ ). Control was maintained with $0.1 \%$ ethanol as vehicle. The plates were incubated for another $24 \mathrm{~h}$ at $37^{\circ} \mathrm{C}$ with the sphingoid bases. The WST-1 reagent $(3.3 \mathrm{mg} / \mathrm{ml}$ phosphate-buffered saline including 7\% 1-methoxy PMS) was added at $10 \mu \mathrm{l}$ in each well containing $100 \mu \mathrm{l}$ of medium with the cells. The plates were incubated an additional $2 \mathrm{~h}$ at $37^{\circ} \mathrm{C}$. Absorbance was measured at $650 \mathrm{~nm}$ on a microplate reader (Bio-Rad, Sunnyvale, CA, USA).
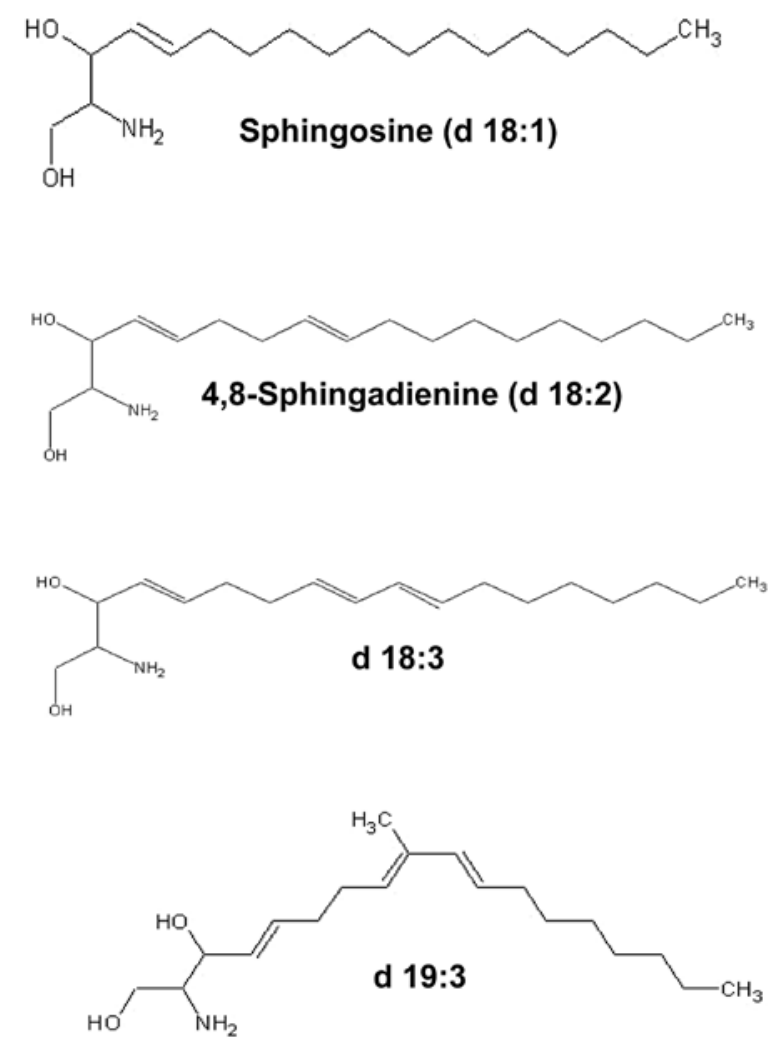

Figure 1. Chemical structure of sphingoid bases extracted from the total lipid of sea cucumber.

Enzyme-linked immunosorbent assay (ELISA) for apoptosis. DNA fragmentation was measured by a biotin-labeled antihistone-antibody and a peroxidase-conjugated anti-DNA antibody cell death detection ELISA kit (Roche Diagnostics $\mathrm{GmbH}$, Mannheim, Germany). In brief, HepG2 cells $\left(2 \times 10^{3}\right.$ cells/well) were plated in 96-well plates with $100 \mu 1$ of medium and incubated for $24 \mathrm{~h}$. After a 24-h incubation, cells were treated with the sphingoid bases for $24 \mathrm{~h}$. The level of cytoplasmic histone-associated DNA fragments (mono- and oligonucleosomes) in HepG2 cells was expressed as an enrichment factor, calculated using the following formula: Enrichment factor $=$ Absorbance of sample (treated)/Absorbance of corresponding control.

Caspase- 3 and -8 activities. Caspase- 3 and -8 activities were measured using a caspase- 3 and -8 colorimetric assay kit (BioVision Research Products, Mountain View, CA, USA). HepG2 cells were treated with the sphingoid bases for $24 \mathrm{~h}$, then harvested and lysed with chilled cell lysis buffer and incubated on ice for $10 \mathrm{~min}$. Cell lysates were clarified by centrifugation at $10,000 \mathrm{xg}$ for $1 \mathrm{~min}$ at $4^{\circ} \mathrm{C}$. The protein concentration in the supernatant was quantified following the method of Lowry et al (35), and $100 \mu \mathrm{g}$ of protein was added to $50 \mu \mathrm{l}$ of lysis buffer for each assay. Fifty microliters of $2 \mathrm{X}$ reaction buffer (containing $10 \mathrm{mM}$ dithiothreitol, DTT) was added to each sample. For caspase- 3 and -8 assays, samples were incubated with Asp-Glu-Val-Asp-p-nitroanilide (DEVD-pNA) substrate for $2 \mathrm{~h}$ at $37^{\circ} \mathrm{C}$. Optical density reading was taken at a wavelength of $405 \mathrm{~nm}$ on a microplate reader. 


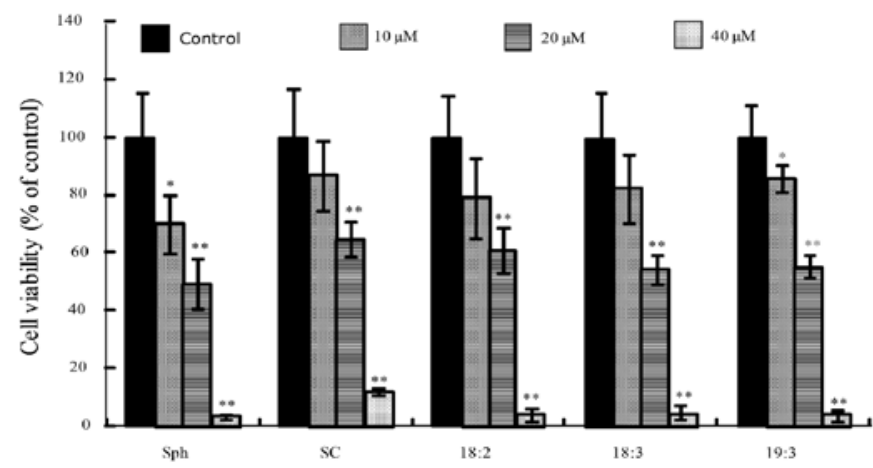

Figure 2. Cell viability of HepG2 cells treated for $24 \mathrm{~h}$ with different concentrations of sphingosine ( $\mathrm{Sph}$ ), sphingoid bases extracted from sea cucumber (SC), 4,8-sphingadienine (18:2), d18:3 and d19:3. Values are means \pm SD. Statistical significance; ${ }^{*} \mathrm{P}<0.05$ and ${ }^{* *} \mathrm{P}<0.01$ as compared to the non-treated control.

Quantitative real-time RT-PCR for $m R N A$ analysis. Quantitative real-time PCR was performed to measure the mRNA levels of the studied genes using a Bio-Rad Thermal Cycler (Bio-Rad Laboratories, Hercules, CA, USA) using SYBR-Green PCR reagents. Total RNA was extracted from the HepG2 cells treated with sphingoid bases using SepasolRNA I Super (Nacalai Tesque Inc., Kyoto, Japan). The following primers were used: PPAR- $\gamma, 5$ '-AAGGCCATTTTC TCAAACGA-3' (sense), 5'-TGCAACCACTGGATCTGT TC-3' (antisense); GADD45, 5'-CAGAAGACCGAAAGG ATGGA-3' (sense), 5'-CAGAAGACCGAAAGGATGGA-3' (antisense); Bax, 5'-TCTGACGGCAACTTCAACTG-3' (sense), 5'-CCTGTAATCCCAGGTCCTTG-3' (antisense). The primer pair of GAPDH was 5'-TGGGATCGAGTGAAG GACCT-3' (sense) and 5'-CTCCTCCTGCCACTTCTTC TG-3' (antisense). The reaction solution (20 $\mu$ l final volume) contained $6 \mu \mathrm{l}$ of sample, $10 \mu \mathrm{l} \mathrm{SYBR-Green} \mathrm{dye} \mathrm{and} 2 \mu \mathrm{l}$ of each primer. The thermal cycling conditions were as follows: $48^{\circ} \mathrm{C}$ for $30 \mathrm{~min}$ to prevent carrying over of DNA, an initial denaturation of $95^{\circ} \mathrm{C}$ for $10 \mathrm{~min}$, followed by 40 cycles of denaturation at $95^{\circ} \mathrm{C}$ for $1 \mathrm{sec}$ and an annealing temperature of $55^{\circ} \mathrm{C}$ for $1 \mathrm{~min}$.

Western blot analysis. Cells were grown in 100-mm culture dishes, starved of serum for $48 \mathrm{~h}$ and treated with sphingoid bases. They were then lysed in cell lysis buffer $[62.5 \mathrm{mM}$ Tris- $\mathrm{HCl}$ (pH 6.8), 2\% SDS, 5\% mercaptoethanol, $2 \mathrm{mM}$ phenylmethylsulfonyl fluoride, protease inhibitors (Roche, Mannheim, Germany)], $1 \mathrm{mM} \mathrm{Na} \mathrm{VO}_{4}, 50 \mathrm{mM} \mathrm{NaF}$ and $10 \mathrm{mM}$ EDTA. Ten micrograms of protein per lane was separated by SDS-polyacrylamide gel electrophoresis and blotted onto nitrocellulose membranes, which were then saturated with 5\% dried milk in Tris-buffered saline containing $0.4 \%$ Tween-20. The blots were incubated with the anti-AKT and anti-phospho-AKT antibodies at a dilution of 1:1,000, and then further incubated with horseradish peroxidase-conjugated secondary antibody. The blots were also incubated with the anti-DR5 and anti-actin antibodies at a dilution of 1:1,000, and then further incubated with horseradish peroxidase-conjugated secondary antibody. Bound antibodies were detected using an Enhanced Chemiluminescence Plus kit (Amersham

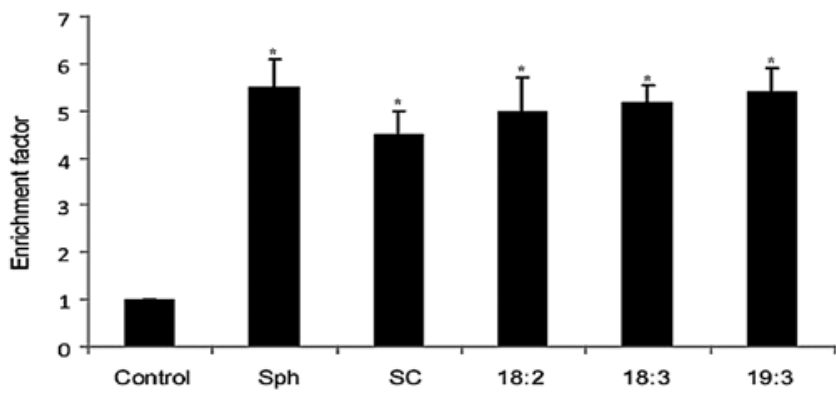

Figure 3. Enrichment factor increment in HepG2 cells treated with sphingosine (Sph), sphingoid bases extracted from sea cucumber (SC), 4,8-sphingadienine (18:2), d18:3 and d19:3. Cells were preincubated without any treatment for $24 \mathrm{~h}$ followed by treatment with Sph, SC, 4,8-sphingadienine (18:2), d18:3 and d19:3 for $48 \mathrm{~h}$. Apoptosis was quantified using an ELISA assay. Results are represented as the relative fold increase in apoptosis as compared with the control. The bars represent $\pm \mathrm{SD}(\mathrm{n}=4)$. ${ }^{*} \mathrm{P}<0.01$ vs. control.

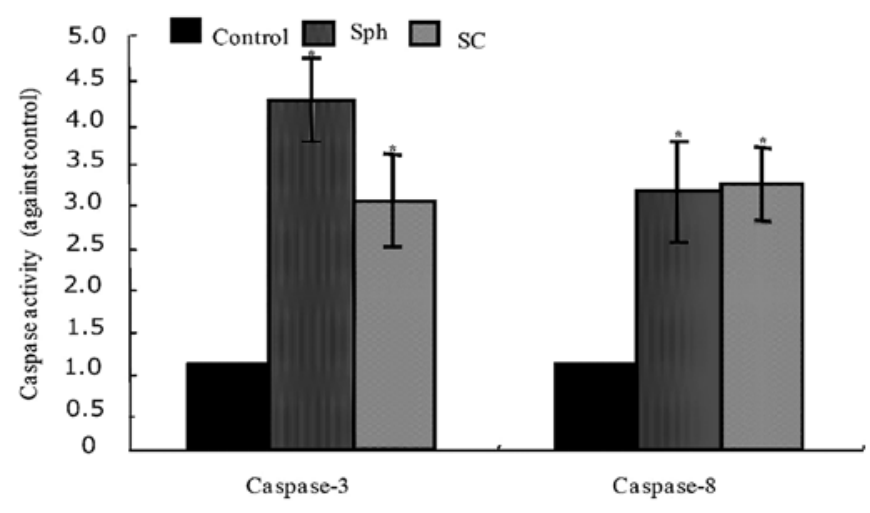

Figure 4. Activity of caspase-3 and -8 in HepG2 cells treated for $24 \mathrm{~h}$ with sphingosine (Sph), and sphingoid bases extracted from sea cucumber (SC). Values are means $\pm \mathrm{SD}$. Statistical significance; ${ }^{*} \mathrm{P}<0.01$ as compared to the non-treated control.

International, Little Chalfont, UK). The results were analyzed using a Fujifilm visualizer (LAS-3000, Fujifilm Corp., Tokyo, Japan).

\section{Results}

Inhibition of HepG2 cell proliferation by sphingoid bases. The effect of sphingoid bases from sea cucumber on the inhibition of HepG2 cell proliferation at various concentrations was tested at $24 \mathrm{~h}$. Sphingoid bases inhibited cell proliferation in a dose-dependent manner. There was significant growth inhibition with 20 or $40 \mu \mathrm{M}$ of the sphingoid bases when compared with the control (Fig. 2). The growth inhibition with sphingosine and sphingoid bases from sea cucumber was comparable (Fig. 2).

Apoptosis induction in HepG2 cells treated with sphingoid bases. To characterize the apoptosis induced by sphingoid bases, an experiment was conducted using a quantitative cell death ELISA. The enrichment factors in cells treated with $20 \mu \mathrm{M}$ sphingoid bases (18:3 or 19:3) were increased by 5.0-fold in comparison to the control (Fig. 3). Sphingosine and sphingoid bases from sea cucumber significantly increased caspase-3 and -8 activities compared to the control (Fig. 4). 

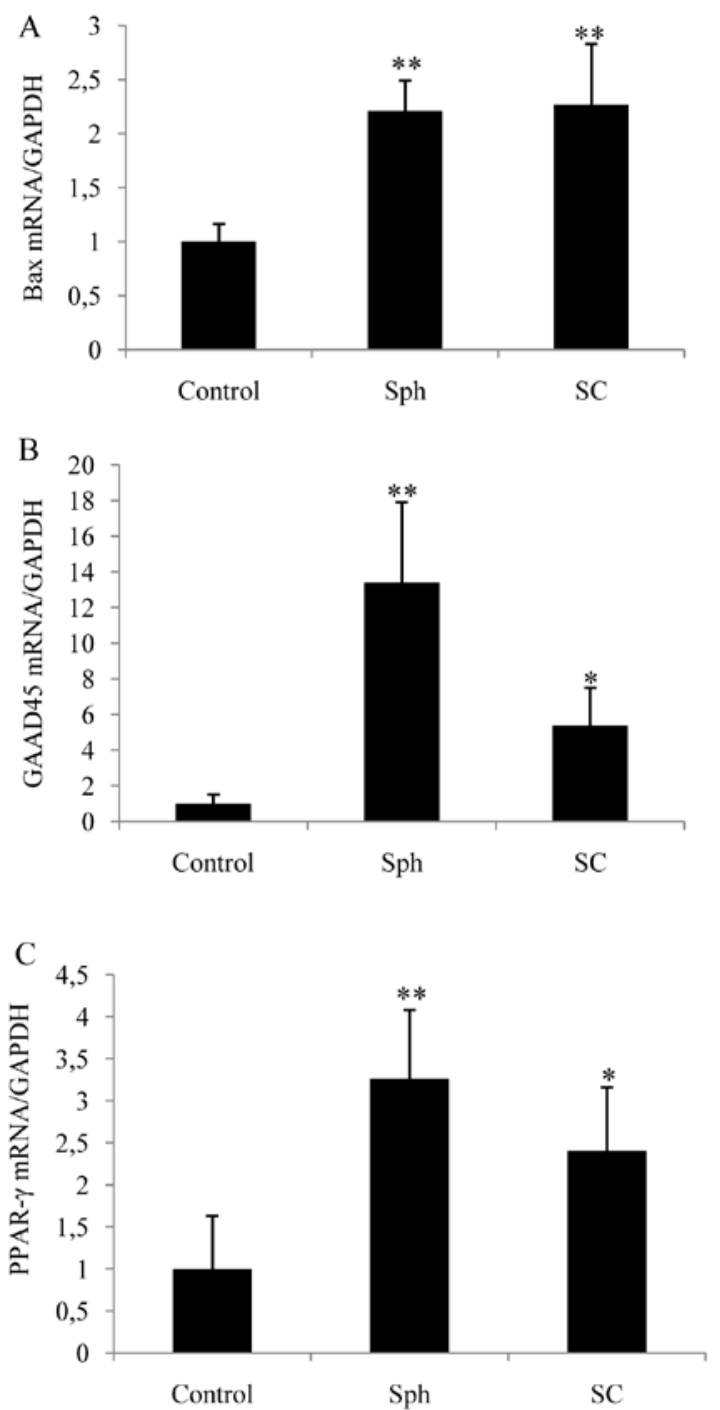

Figure 5. Effect of treatment with sphingosine (Sph) and sphingoid bases extracted from sea cucumber (SC) on the expression level of Bax (A), GADD45 (B) and PPAR $\gamma(\mathrm{C})$ mRNA in HepG2 cells. HepG2 cells were incubated in cultured medium with Sph and SC for $24 \mathrm{~h}$. Expression of Bax, GADD45 and PPAR $\gamma$ mRNA was determined by real-time quantitative RT-PCR analysis. Data from 3 independent experiments were normalized to GAPDH mRNA levels and are shown as the means $\pm \mathrm{SD}$. ${ }^{*} \mathrm{P}<0.05$ vs. control, ${ }^{* *} \mathrm{P}<0.01$ vs. control.

Bax, GADD45 and PPAR $\gamma$ expression in HepG2 cells treated with sphingoid bases. The expression level of Bax, GADD45 and PPAR $\gamma$ mRNA in HepG2 cells was increased following a 24-h incubation with $20 \mu \mathrm{M}$ sphingoid bases. Treatment with the sphingoid bases of sea cucumber increased the expression of Bax, GADD45 and PPAR $\gamma$ by only 3.0-, 2.0 and 2.5-fold in the HepG2 cells whereas sphingosine increased their expression levels by 6.0-, 2.0- and 3.0-fold respectively, compared with the control (Fig. 5).

Expression of $p$-AKT decreased and expression of DR5 increased due to the effects of treatment with the sphingoid bases. To clarify whether the expression levels of p-AKT are associated with the effects of sphingoid bases, we measured expression of AKT and p-AKT by immunoblot analysis. AKT, which is the downstream effector of PI3-kinase was found to be phosphorylated. We found that sphingoid bases induced p-AKT inhibition and triggered apoptosis (Fig. 6A). To clarify whether the expression levels of DR5 are associated with the effects of sphingoid bases, we measured the expression of DR5 by immunoblot analysis. We found that treatment with the sphingoid bases increased expression of DR5 in the HepG2 cells (Fig. 6B).

\section{Discussion}

Dietary sphingolipids have gained attention for their potential to protect against the development of colon cancer. Sphingolipids are a family of compounds that have a longchain (sphingoid) base backbone and include free sphingoid bases (sphingosine and sphinganine), ceramides, sphingomyelins, cerebrosides, sulfatides and gangliosides (36). Several studies have been conducted with milk sphingomyelin, synthetic sphingomyelin, synthetic dihydrosphingomyelin, as well as milk glycosphingolipids to determine 1,2-dimethylhydrazine (DMH)-induced colon cancer protection in CF1 mice. Sphingomyelin at $0.1 \%$ of the diet caused a higher percentage of adenomas and a lower percentage of more advanced adenocarcinomas. Notably, synthetic dihydrosphingomyelin (N-palmitoyl dihydrosphingomyelin) more potently reduced the number of aberrant colonic foci than synthetic sphingomyelin (N-palmitoylsphingomyelin) and milk sphingomyelin, suggesting that the 4,5-trans double bond, which is absent in dihydrosphingomyelin, is not required for the suppression of colon carcinogenesis (37). In the current study, we found that the growth suppression effects of sphingosine and sphingoid bases from sea cucumber (mixture of bases, 18:3 and 19:3), and a maize sphingoid base (18:2) in HepG2 cells were comparable. The long chain structure and 3 double bonds present in the bases of sea cucumber may be indispensable for the apoptotic effect of sphingoid bases on cancer cells.

Activation of the caspase cascade, a family of cysteine proteases, is required for apoptotic signaling. In addition to their crucial role as the energy-producing center of the cell, the mitochondria are central to the convergence of the intrinsic or extrinsic cellular signal transduction pathways that result in apoptosis. Essential to this process is the release of cytochrome $c$ and other mitochondrial-related proteins that are normally confined to the mitochondrial intermembrane space by antiapoptotic Bcl-2 family members $(38,39)$. Recent data suggest that oligomeric Bax is a component of the mitochondrial apoptosis-induced channel, and following their interaction, a selective cytochrome $c$ release pore is formed (40). However, the consensus of these theories includes a requirement for Bax/Bak activation to promote pore opening and cytochrome $c$ release. Our data showed an increased mRNA expression of Bax. The release of cytochrome $c$ and other apoptogenic factors from injured mitochondria have been shown to activate caspases (41), and the mitochondrial integrity appears to be regulated, in part, by members of the Bcl-2 family. In response to apoptotic signals, Bax, a proapoptotic member of this family, is redistributed from the cytosol to the mitochondria, where it decreases membrane potential leading to cytochrome $c$ release and caspase activation (42).

Little is known concerning the direct action of sphingolipids on the expression of genes in hepatocytes. In the 
A

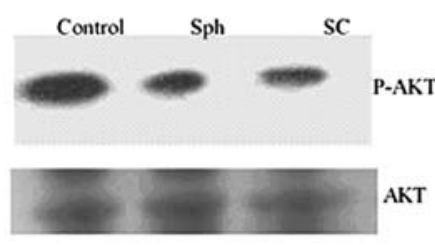

B

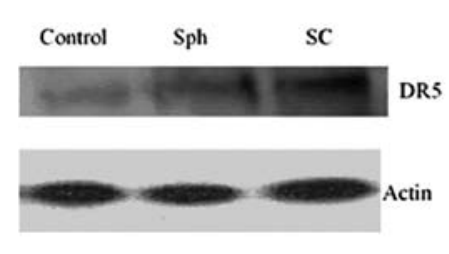

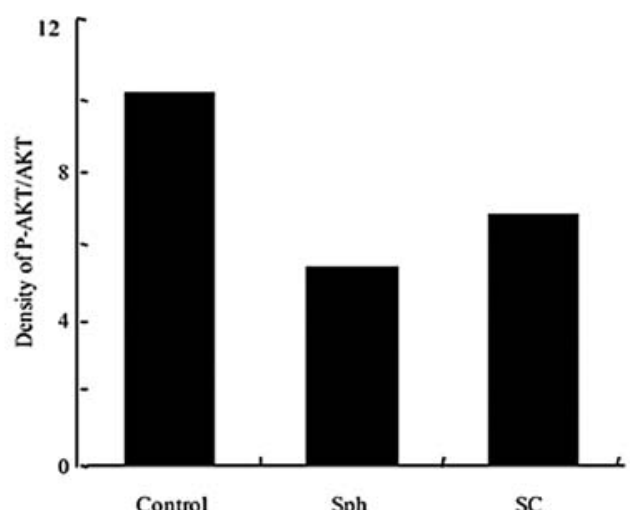

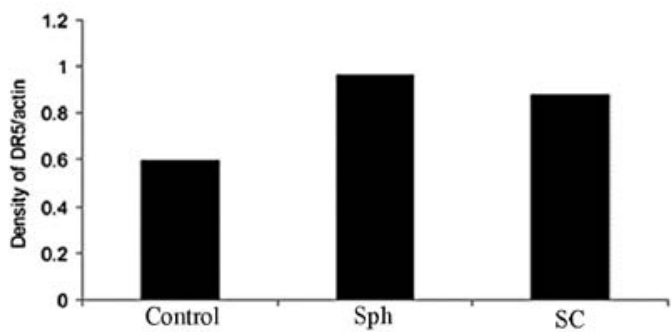

Figure 6. Effect of treatment with sphingosine (Sph) and sphingoid bases extracted from sea cucumber (SC) on the expression of p-AKT and DR5 in HepG2 cells. (A) HepG2 cells were incubated in cultured medium with Sph and SC for $24 \mathrm{~h}$. Expression of p-AKT was determined by western blot analysis. Data from the experiment was normalized to AKT as a control. (B) HepG2 cells were incubated in cultured medium with Sph and SC for $24 \mathrm{~h}$. Expression of DR5 was determined by western blot analysis. Data from the experiment was normalized to actin as a control.

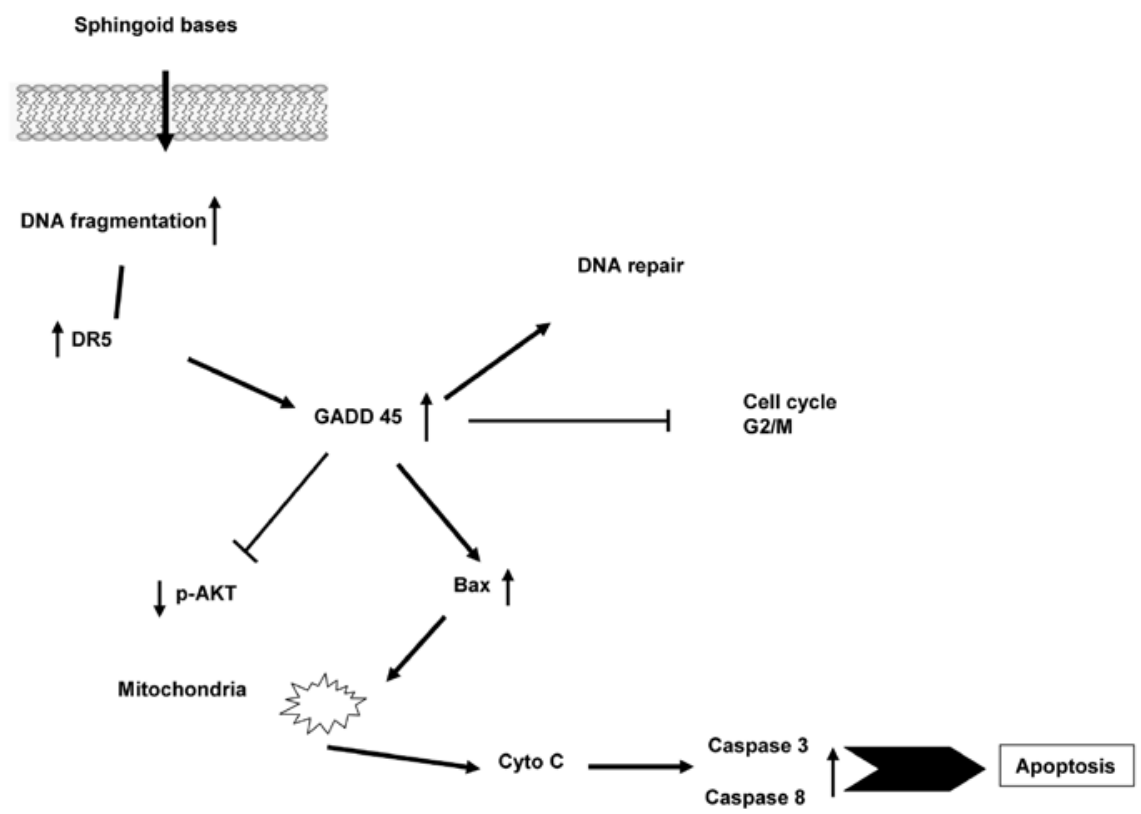

Figure 7. Illustration of the pathway of apoptosis induced by sphingoid bases extracted from sea cucumber (SC). SC upregulates DR5, GADD45, Bax, caspase-3 and -8 and downregulates p-AKT.

present study, we also found the increased mRNA expression of PPAR $\gamma$ in HepG2 cells. PPAR $\gamma$ displayed proapoptotic activity, as has been demonstrated in the HL-60 cell line (43) and in the lymphoblastic leukemia cell line (44). PPAR $\gamma$ liagands 15d-PGJ2 and troglitazone suppress DNA synthesis and induce apoptosis in HT-29 colon cancer cells (45). Troglitazone inhibited the growth of liver cancer cells PLC/PRF/5, HepG2 and HuH-7, by inducing apoptosis through caspase-3 activation (46). GADD $45 \alpha$ overexpression in normal human fibroblasts and human cancer cells was found to cause G2-M arrest (47-49). GADD45 $\alpha$-dependent induction of apoptosis has been observed frequently in cancer cell lines $(50,51)$, but its role in apoptosis induction in normal cells has been controversial. GADD $45 \alpha$ has been 
shown to induce cell cycle arrest in normal fibroblasts but failed to induce apoptosis (48). Others, however, have shown Gadd $45 \alpha$-dependent induction of apoptosis in normal epithelial cells (52). In the present study, we showed that GADD45 expression correlated with a significant increase in apoptosis in HepG 2 cells. In this study, we characterized the functional role of AKT in the apoptotic pathway related to the sphingoid bases and we found that inhibition of the activation of $\mathrm{AKT}$ is one of the mechanisms by which sphingoid bases induced apoptosis. Our findings concurred with the results of Chang et al (5) who found that sphingosine induced apoptosis by inhibiting AKT expression. AKT is known to inhibit apoptosis by inactivating proapoptotic proteins such as Bad, procaspase-9, and forkhead and by activating antiapoptotic proteins such as NF- $\kappa \mathrm{B}$ and cyclic adenosine monophosphate (cAMP)-response element binding protein $(53,54)$. A previous study showed that dephosphorylation of AKT activates the proapoptotic function of Bax (55). Based on these observations, inhibition of AKT phosphorylation by sphingoid bases may lead to inhibition of Bax phosphorylation that promotes Bax translocation into the mitochondrial membrane.

Based on our results, we propose an outline of the sphingoid base-induced apoptotic signaling pathway (Fig. 7). Sphingoid bases induce DNA fragmentation resulting in the upregulation of GADD45, which induces cell cycle arrest in the G2/M phase giving cells the chance to repair DNA damage. In contrast, when DNA damage is not repaired, cells execute the apoptotic pathway. GADD45, DR5 and Bax are upregulated and p-AKT is downregulated, leading to the disruption of the mitochondrial membrane, which in turn causes cytochrome $c$ release from the intramitochondria into the cytosol, thus activating caspase- 3 and -8 , which then cleaves the death substrates, leading to apoptosis. Sea cucumber is consumed as a food in different regions of the world. Prevention of cancer by supplementing the diet with naturally occurring compounds is considered as a potential approach to reduce cancer.

\section{Acknowledgements}

This study was supported by the Japan Society for the Promotion of Science (JSPS) and the Program for Promotion and Applied Research for Innovations in the Bio-Oriented Industry (BRAIN).

\section{References}

1. Parkin DM: The global health burden of infection-associated cancers in the year 2002. Int J Cancer 118: 3030-3044, 2006.

2. But DY, Lai CL and Yuen MF: Natural history of hepatitis-related hepatocellular carcinoma. World J Gastroenterol 14: 1652-1656, 2008.

3. Liu S, Xie J, Yin J, Zhang H, Zhang Q, Pu R, Li C, Ni W, Wang H and Cao G: A matched case-control study of hepatitis B virus mutations in the preS and core promoter regions associated independently with hepatocellular carcinoma. J Med Virol 83: 45-53, 2011.

4. Huwiler A, Kolter T, Pfeilschifter J and Sandhoff K: Physiology and pathophysiology of sphingolipid metabolism and signaling. Biochim Biophys Acta 1485: 63-99, 2000.

5. Chang HC, Tsai LH, Chuang LY and Hung WC: Role of AKT kinase in sphingosine-induced apoptosis in human hepatoma cells. J Cell Physiol 188: 188-193, 2001.

6. Ruvolo PP: Intracellular signal transduction pathways activated by ceramide and its metabolites. Pharmacol Res 47: 383-392, 2003.
7. Maceyka M, Payne SG, Milstien S and Spiegel S: Sphingosine kinase, sphingosine-1-phosphate, and apoptosis. Biochim Biophys Acta 1585: 193-201, 2002.

8. Orgetmen B and Hannun YA: Biologically active sphingolipids in cancer pathogenesis and treatment. Nat Rev Cancer 4: 604-616, 2004.

9. Yamada K: Chemo-pharmaceutical studies on the glycosphingolipid constituents from echinoderm, sea cucumbers, as medicinal materials. Yakugaku Zasshi 122: 1133-1143, 2002 (In Japanese).

10. Yamada K, Hamada A, Kisa F, Miyamoto T and Higuchi R: Constituents of holothuroidea, 13. Structure of neuritogenic active ganglioside molecular species from the sea cucumber Stichopus chloronotus. Chem Pharm Bull 51: 46-52, 2003.

11. Sugawara T, Zaima N, Yamamoto A, Sakai S, Noguchi R and Hirata T: Isolation of sphingoid bases of sea cucumber cerebrosides and their cytotoxicity against human colon cancer cells. Biosci Biotechnol Biochem 70: 2906-2912, 2006.

12. Sugawara $\mathrm{T}$ and Miyazawa T: Separation and determination of glycolipids from edible plant sources by high-performance liquid chromatography and evaporative light-scattering detection. Lipids 34: 1231-1237, 1999.

13. Sugawara T, Aida K, Duan J and Hirata T: Analysis of glucosylceramides from various sources by liquid chromatography-ion trap mass spectrometry. J Oleo Sci 59: 387-394, 2010.

14. Hossain Z, Sugawara T, Aida K and Hirata T: Effect of dietary glucosylceramides from sea cucumber on plasma and liver lipids in cholesterol-fed mice. Fish Sci 77: 1081-1085, 2011.

15. Sugawara T, Kinoshita M, Ohnishi M and Miyazawa T: Apoptosis induction by wheat-flour sphingoid bases in DLD-1 human colon cancer cells. Biosci Biotech Biochem 66: 2228-2231, 2002.

16. Aida K, Kinoshita M, Sugawara T, Ono J, Miyazawa T and Ohnishi M: Apoptosis inducement by plant and fungus sphingoid bases in human colon cancer cells. J Oleo Sci 53: 503-510, 2004.

17. Kanno T and Nishizaki T: Sphingosine induces apoptosis in hippocampal neurons and astrocytes by activating caspase-3/-9 via a mitochondrial pathway linked to SDK/14-3-3 protein/Bax/ cytochrome $c$. J Cell Physiol 226: 2329-2337, 2011.

18. Clay CE, Atsumi GI, High KP and Chilton FH: Early de novo gene expression is required for 15-deoxy-Delta 12,14-prostaglandin J2-induced apoptosis in breast cancer cells. J Biol Chem 276: 47131-47135, 2001.

19. Debrock G, Vanhentenrijk V, Sciot R, Debiec-Rychter M, Oyen R and Van Oosterom A: A phase II trial with rosiglitazone in liposarcoma patients. Br J Cancer 89: 1409-1412, 2003.

20. Grommes C, Landreth GE and Heneka MT: Antineoplastic effects of peroxisome proliferator-activated receptor gamma agonists. Lancet Oncol 5: 419-429, 2004.

21. Date M, Fukuchi K, Morita S, Takahashi $\mathrm{H}$ and Ohura K: 15-Deoxy-delta12,14-prostaglandin J2, a ligand for peroxisome proliferator-activated receptor-gamma, induces apoptosis in human hepatoma cells. Liver Int 23: 460-466, 2003.

22. Han S, Sidell N, Fisher PB and Roman J: Up-regulation of p21 gene expression by peroxisome proliferator-activated receptor gamma in human lung carcinoma cells. Clin Cancer Res 10: 1911-1919, 2004.

23. Yang FG, Zhang ZW, Xin DQ, Shi CJ, Wu JP, Guo YL and Guan YF: Peroxisome proliferator-activated receptor gamma ligands induce cell cycle arrest and apoptosis in human renal carcinoma cell lines. Acta Pharmacol Sin 26: 753-761, 2005.

24. Shigeto T, Yokoyama Y, Xin B and Mizunuma H: Peroxisome proliferator-activated receptor alpha and gamma ligands inhibit the growth of human ovarian cancer. Oncol Rep 18: 833-840, 2007.

25. Lin MS, Chen WC, Bai X and Wang YD: Activation of peroxisome proliferator-activated receptor gamma inhibits cell growth via apoptosis and arrest of the cell cycle in human colorectal cancer. J Dig Dis 8: 82-88, 2007.

26. Sporn MB, Suh N and Mangelsdorf DJ: Prospects for prevention and treatment of cancer with selective PPAR $\gamma$ modulators (SPARMs). Trends Mol Med 7: 395-400, 2001.

27. Gupta RA and Dubois RN: Controversy: PPAR $\gamma$ as a target for treatment of colorectal cancer. Am J Physiol 283: G266-G269, 2002.

28. Girnun GD, Smith WM, Drori S, Sarraf P, Mueller E, Eng C, Nambiar P, Rosenberg DW, Bronson RT, Edelmann W, Kucherlapati R, Gonzalez FJ and Spiegelman BM: APCdependent suppression of colon carcinogenesis by PPAR $\gamma$. Proc Natl Acad Sci USA 99: 13771-13776, 2002. 
29. Yasui Y, Hosokawa M, Sahara T, Suzuki R, Ohgiya S, Kohno H, Tanaka T and Miyashita K: Bitter gourd seed fatty acid rich in 9c,11t,13t-conjugated linolenic acid induces apoptosis and up-regulates the GADD45, p53 and PPARgamma in human colon cancer Caco-2 cells. Prostaglandins Leukot Essent Fatty Acids 73: 113-119, 2005.

30. Han C, Demetris AJ, Michalopoulos GK, Zhan Q, Shelhamer JH and $\mathrm{Wu}$ T: PPAR $\gamma$ ligands inhibit cholangiocarcinoma cell growth through p53-dependent GADD45 and p21 WAF1/Cip1 pathway. Hepatology 38: 167-177, 2003.

31. Nagamine M, Okumura T, Tanno S, Sawamukai M, Motomura W, Takahashi N and Kohgo Y: PPAR $\gamma$ ligand-induced apoptosis through a p53-dependent mechanism in human gastric cancer cells. Cancer Sci 94: 338-343, 2003.

32. Okumura T, Nakamura M, Takata Y, Watanabe S, Kitami Y and Hiwada K: Troglitazone induces apoptosis via the p53 and Gadd45 pathway in vascular muscle cells. Eur J Pharmacol 407: 227-235, 2000

33. Yin F, Bruemmer D, Blaschke F, Hsueh WA, Law RE and Van Herle AJ: Signaling pathways involved in induction of GADD45 gene expression and apoptosis by troglitazone in human MCF-7 breast carcinoma cells. Oncogene 23: 4614-4623, 2004.

34. Aida K, Kinoshita M, Tanji M, Sugawara T, Tamura M, Ono J, Ueno $\mathrm{N}$ and Ohnishi M: Prevention of aberrant crypt foci formation by dietary maize and yeast cerebrosides in 1,2-dimethylhydrazine-treated mice. J Oleo Sci 54: 45-49, 2005.

35. Lowry OH, Rosebrough NJ, Farr AL and Randall RJ: Protein measurement with the Folin phenol reagent. J Biol Chem 193: 265-275, 1951

36. Merrill AH Jr, Schmelz EM, Dillehay DL, Spiegel S, Shayman JA, Schroeder JJ, Riley RT, Voss KA and Wang E: Sphingolipids: the enigmatic lipid class: biochemistry, physiology, and pathophysiology. Toxicol Appl Pharmacol 142: 208-225, 1997.

37. Schmelz EM, Sullards MS, Dillehay DL and Merrill AH Jr: Colonic cell proliferation and aberrant crypt foci formation are inhibited by dairy glycosphingolipids in 1,2-dimethylhydrazinetreated CF1 mice. J Nutr 130: 522-527, 2000.

38. Sprick MR and Walczak $\mathrm{H}$ : The interplay between the Bcl-2 family and death receptor-mediated apoptosis. Biochim Biophys Acta 1644: 125-132, 2004.

39. Willis SN and Adams JM: Life in the balance: how BH3-only proteins induce apoptosis. Curr Opin Cell Biol 17: 617-625, 2005.

40. Dejean LM, Martinez-Caballero S, Guo L, Hughes C, Teijido O Ducret T, Ichas F, Korsmeyer SJ, Antonsson B, Jonas EA and Kinnally KW: Oligomeric Bax is a component of the putative cytochrome $c$ release channel MAC, mitochondrial apoptosisinduced channel. Mol Biol Cell 16: 2424-2432, 2005.

41. Scaffidi C, Schmitz I, Zha J, Korsmeyer SJ, Krammer PH and Peter ME: Differential modulation of apoptosis sensitivity in CD95 type I and type II cells. J Biol Chem 274: 22532-22538, 1999.
42. Gross A, Jockel J, Wei MC and Korsmeyer SJ: Enforced dimerization of BAX results in its translocation, mitochondrial dysfunction and apoptosis. EMBO J 17: 3878-3885, 1998.

43. Laurora S, Pizzimenti S, Briatore F, Fraioli A, Maggio M, Reffo P, Ferretti C, Dianzani MU and Barrera G: Peroxisome proliferator-activated receptor ligands affect growth-related gene expression in human leukemic cells. J Pharmacol Exp Ther 305: 932-942, 2003

44. Liu H, Zang C, Fenner MH, Liu D, Possinger K, Koeffler HP and Elstner E: Growth inhibition and apoptosis in human Philadelphia chromosome-positive lymphoblastic leukemia cell lines by treatment with the dual PPAR $\alpha / \gamma$ ligand TZD18. Blood 107: 3683-3692, 2006.

45. Shimada T, Kojima K, Yoshiura K, Hiraishi H and Terano A: Characteristics of the peroxisome proliferator activated receptor $\gamma$ (PPAR $\gamma$ ) ligand induced apoptosis in colon cancer cells. Gut 50: 658-664, 2002.

46. Toyoda M, Takagi H, Horiguchi N, Kakizaki S, Sato K, Takayama $\mathrm{H}$ and Mori M: A ligand for peroxisome proliferator activated receptor gamma inhibits cell growth and induces apoptosis in human liver cancer cells. Gut 50: 563-567, 2002.

47. Wang W, Huper G, Guo Y, Murphy SK, Olson JA Jr and Marks JR: Analysis of methylation-sensitive transcriptome identifies GADD $45 \alpha$ as a frequently methylated gene in breast cancer. Oncogene 24: 2705-2714, 2005.

48. Mita H, Tsutsui J, Takekawa M, Witten EA and Saito $\mathrm{H}$ : Regulation of MTK1/MEKK4 kinase activity by its N-terminal autoinhibitory domain and GADD45 binding. Mol Cell Biol 22: 4544-4555, 2002.

49. Tront JS, Hoffman B and Liebermann DA: Gadd $45 \alpha$ suppresses Ras driven mammary tumorigenesis by activation of c-Jun $\mathrm{NH} 2$-terminal kinase and p38 stress signaling resulting in apoptosis and senescence. Cancer Res 66: 8448-8454, 2006.

50. Zerbini LF and Libermann TA: ADD45 deregulation in cancer: frequently methylated tumor suppressors and potential therapeutic targets. Clin Cancer Res 11: 6409-6413, 2005.

51. Tong T, Ji J, Jin S, Li X, Fan W, Song Y, Wang M, Liu Z, Wu M and Zhan Q: Gadd45 $\alpha$ expression induces Bim dissociation from the cytoskeleton and translocation to mitochondria. Mol Cell Biol 25: 4488-4500, 2005.

52. Hildesheim J, Bulavin DV, Anver MR, Alvord WG, Hollander MC, Vardanian L and Fornace AJ Jr: Gadd45 $\alpha$ protects against UV irradiation-induced skin tumors, and promotes apoptosis and stress signaling via MAPK and p53. Cancer Res 62: 7305-7315, 2002.

53. Zhou H, Li XM, Meinkoth J and Pittman RN: Akt regulates cell survival and apoptosis at a postmitochondrial level. J Cell Biol 151: 483-494, 2000.

54. Testa JR and Bellacosa A: Akt plays a central role in tumorigenesis. Proc Natl Acad Sci USA 98: 10983-10985, 2001.

55. Xin $M$ and Deng X: Nicotine inactivation of proapoptotic function of Bax through phosphorylation. J Biol Chem 280: 10781-10789, 2005. 